\title{
APLIKASI SISTEM INFORMASI GEOGRAFIS PADA PEMANTAUAN STATUS GIZI BALITA DI DINAS KESEHATAN KABUPATEN SUKOHARJO
}

\author{
Mutalazimah *, Bana Handaga ** dan Agus Anggoro Sigit *** \\ * Program Studi Gizi Fakultas Ilmu Kesehatan Universitas Muhammadiyah Surakarta \\ E-mail : mutalazimah@ums.ac.id \\ ** Jurusan Elektro Fakultas Teknik Universitas Muhammadiyah Surakarta \\ E-mail : bana.handaga@yahoo.com \\ *** Fakultas Geografi Universitas Muhammadiyah Surakarta \\ E-mail : anggoro.sigit@yahoo.com
}

\begin{abstract}
The research was conducted to develop the information system model on nutrition status of child monitoring based on geographical information system (GIS) to support the plan of increasing the nutrition improvement at the District Health Office, Sukoharjo Regency. This descriptive research was carried out by implementing interview to subjects who were involved in the activity of the monitoring. Observation was also performed to two objects, namely the structure and the procedure of information. The collected data were analyzed descriptively by applying result of structure and the procedure analysis. The system development was designed by using the approach of FAST (Framework for the Application of System Techniques). The observation to the problem, scope, and property had been conducted by the interview with the subjects indicate that the research subjects at all levels from top managers to persons in the transactional level as well as those who are at cross section department support the development of monitoring system to the improvement of nutrition status program, and this system is reliable to maping perform of nutrition status of child based on the category as severe malnutrition, under nutrition, normal and overweigt. In the future nutrition information based on GIS have the benefits of the new system in supporting the monitoring activity toward the nutrition improvement program and it also supports the plan. Suggestions from this research might go to the government health institution to develop spatial or terrestrial data on the health programs have to be designed GIS for the each other program. Moreover, the other model should be developed GIS in the other spatial data and information can be accessed by informative map.
\end{abstract}

Keywords: GIS, monitoring, nutrition status of child 


\section{PENDAHULUAN}

Program perbaikan gizi makro diarahkan untuk menurunkan masalah gizi makro yang utamanya mengatasi masalah kurang energi protein terutama di daerah miskin baik di pedesaan maupun di perkotaan dengan meningkatkan keadaan gizi keluarga, meningkatkan partisipasi masyarakat, meningkatkan kualitas pelayanan gizi baik di puskesmas maupun di posyandu, dan meningkatkan konsumsi energi dan protein pada balita gizi buruk. Evaluasi juga dilaksanakan dalam pelaksanaan program perbaikan gizi makro, yaitu dimulai dari evaluasi input, proses, output dan impak dengan tujuan untuk menilai persiapan, pelaksanaan, pencapaian target dan prevalensi status gizi pada sasaran (Depkes RI, 2002).

Gizi buruk merupakan salah satu bentuk manifestasi dari adanya gangguan pada proses pertumbuhan. Pertumbuhan balita dapat diartikan sebagai perubahan dalam jumlah, ukuran dan fungsi sel atau organ tubuh yang terjadi pada balita. Pertumbuhan diukur dengan ukuran berat (gram, kilogram), ukuran panjang (cm, meter), umur tulang dan keseimbangan metabolik (Supariasa dkk, 2002).

Indikator paling sederhana untuk menentukan normal atau tidaknya pertumbuhan balita yakni dengan melihat kondisi fisik atau yang disebut sebagai status gizi dengan metode antropometri. Parameter yang paling mudah dan sesuai untuk mengukur status gizi balita adalah berat badan, tinggi badan atau panjang badan dan umur, dengan indeks yang digunakan adalah BB/U, BB/TB dan TB/ U. Metode perhitungan menggunakan rumus z-skor dengan standar median berat badan atau tinggi badan dibagi dengan simpangan bakunya (Supariasa dkk, 2002), sehingga secara manual perhitungan z-skor cukup rumit untuk dilakukan apalagi bila jumlah balita yang diukur status gizinya tergolong besar.

Fokus dari pengembangan sistem informasi kesehatan di kabupaten diarahkan untuk mendukung pengambilan keputusan manajemen yang diperlukan dalam rangka perbaikan pelayanan dan program kesehatan secara langsung. Sering terjadi pengumpulan data cukup memadai yang dilakukan melalui informasi rutin oleh pemegang program atau melalui survei khusus namun data atau informasi tersebut mungkin tidak dianalisis secara memadai atau tidak dapat diakses secara tepat waktu dan untuk unit pemakai yang benar (Depkes RI, 2001).

Peningkatkan performance dan kinerja dari sistem informasi PSG tersebut diperlukan pengembangan sistem informasi berbasis komputer dengan pendekatan spasial yakni dengan membuat software yang secara spesifik dapat digunakan untuk memudahkan input data, proses pengolahan dan analisis data, pembuatan pelaporan hasil kegiatan PSG secara lebih lengkap dan cepat serta penyajian data berupa pemetaan wilayah berdasarkan indikator distribusi cakupan gizi baik, gizi kurang dan gizi buruk. Agar informasi yang terkait kewilayahan dapat dikelola dengan baik maka dapat dilakukan dengan Sistem informasi geografis (SIG) (Hartono, et al., 2005). Kelebihan dikembangkannya sistem informasi berbasis komputer dengan pendekatan geografis ini ialah dapat disajikan data-data status gizi balita berupa peta yang lebih mudah dipahami dan lebih informatif sehingga lebih memudahkan pelaksanaan evaluasi kegiatan dan perencanaan intervensi gizi disesuaikan dengan kondisi wilayah. 
SIG merupakan suatu sistem berbasis komputer yang digunakan untuk mengumpulkan, menyimpan, menggabungkan, mengatur, mentranformasi, memanipulasi dan menganalisis data-data geografis. Data geografis yang dimaksud adalah data spasial yang terdiri atas lokasi eksplisit suatu geografi yang diset ke dalam bentuk koordinat berupa raster dan image (Ridwan, 2008).

SIG bisa digunakan untuk memutuskan kebijakan berdasarkan atas data-data kependudukan pada aplikasi enanganan gizi dan kesehatan. Selanjutnya, berdasarkan sistem informasi tersebut kita dapat menarik informasi dari peta yang tersedia dalam aplikasi SIG tersebut, atau sebaliknya, memperoleh informasi mengenai peta kawasan tertentu manakah yang akan muncul, jika kita menggunakan informasi tertentu sebagai kriteria pencariannya, sehingga pengambilan keputusan akan lebih mudah dan tepat sasaran.

Dinas Kabupaten Sukoharjo khususnya di Seksi Gizi, kegiatan pemantauan pertumbuhan balita dilakukan pada 12 kecamatan dengan jumlah desa keseluruhan sebanyak 167 desa, dari hasil PSG tahun 2007 ditemukan ada 177 anak balita menderita gizi buruk. Dari kegiatan tersebut pengolahan dan analisis data hasil masih dilakukan secara manual, mulai dari proses input data, proses penghitungan status gizi, sampai pada interpretasi pengkategorian status gizi yang tentu saja ini membutuhkan waktu yang relatif lebih lama dan memberikan peluang kesalahan input data serta kesalahan penghitungan yang akan dapat mempengaruhi hasil analisis dan pengambilan keputusan.

Hasil pengembangan sistem berbasis teknologi informasi yang dilakukan oleh
Mutalazimah dan Handaga (2005) di Kabupaten Sleman menunjukkan adanya perbedaan kinerja sebelum dan sesudah dikembangkan sistem informasi berbasis komputer pada kegiatan pemantauan garam beryodium. Masih dari hasil penelitian Mutalazimah dan Handaga (2006) mengenai pengembangan sistem informasi pemantauan status gizi juga menunjukkan hasil adanya perbaikan kinerja sistem. Dengan demikian penelitian ini ingin dikembangkan pada kegiatan lain yakni pemantauan pertumbuhan balita yang berbasis sistem informasi geografis.

Sistem informasi berbasis SIG ini sangat mendukung kegiatan PSG menjadi lebih baik terutama dari sisi proses pengolahan, analisis data, penyajian data dan pelaporan agar lebih mudah, cepat, lengkap dan tepat waktu serta sesuai dengan kondisi setiap wilayah. Dengan demikian segala pengambilan keputusan yang terkait dengan kebijakan penanganan gizi buruk dan perbaikan gizi menjadi lebih cepat dan tepat.

Tujuan penelitian ini adalah mengembangkan aplikasi SIG untuk mendukung kegiatan pemetaan status gizi balita, sedangkan manfaatnya adalah dengan diterapkannya SIG pada kegiatan pemetaan status gizi balita ini diharapkan dapat meminimalisir kesalahan-kesalahan pengolahan data dan keterlambatan pelaporan, sehingga permasalahan yang berkaitan dengan masalah gizi dapat ditekan sekecil-kecilnya, intervensi yang dilakukan sesuai dengan kondisi dan sasaran yang tepat sehingga status gizi dan derajat kesehatan di masa mendatang menjadi lebih optimal.

Menurut Almatsier (2001) status gizi adalah keadaan tubuh sebagai akibat konsumsi makanan dan penggunaan zat - 
zat gizi. Jadi dapat disimpulkan bahwa status gizi adalah merupakan suatu kondisi atau keadaan tubuh yang diakibatkan oleh makanan yang dikonsumsi, penyerapan dan penggunaan makanan oleh tubuh.

Status gizi dapat diukur secara langsung melalui pengukuran antropometri, biokimia, biofisik dan klinis. Antropometri merupakan cara pengukuran status gizi yang murah dan mudah dilaksanakan tetapi dengan syarat alat ukur dan pengukurannya harus benar. Ukuran antropometri yang biasa dilakukan pada balita adalah dengan menggunakan indeks BB/U, TB/U, BB/TB.

Penentuan status gizi mengacu pada WHO NCHS (World Health OrganizationNational Center For Health Statistic). Adapun klasifikasi Z-score pada penggunaan indeks $\mathrm{BB} / \mathrm{U}$ adalah sebagai berikut kategori gizi lebih bila nilai $z>+2$ $\mathrm{SD}$, gizi baik bila nilai $\mathrm{z}:+2 \mathrm{~s} / \mathrm{d}-2 \mathrm{SD}$, gizi kurang bila nilai $z$ : $-2 \mathrm{SD}$ s/d $-3 \mathrm{SD}$ dan gizi buruk bila nilai $z<-3 S D$. Metode yang digunakan untuk menentukan status gizi balita tersebut dengan menggunakan metode $z$-score dengan rumus Z-Score = BB aktual - BB Median/Simpang baku. Zscore adalah nilai simpang baku yang menunjukkan status gizi, BB aktual adalah berat badan balita hasil penimbangan, $\mathrm{BB}$ median adalah berat badan standar yang dapat di lihat pada tabel WHO-NCHS, simpang baku adalah selisih antara BB Median dengan $+1 /-1$ standar deviasi. (Depkes RI, 2002)

Kegiatan selanjutnya dari pemantauan status gizi balita setelah penghitungan status gizi adalah membuat kategori seperti yang telah ditentukan yakni gizi lebih, gizi baik, gizi kurang dan gizi buruk, selanjutnya dicari prevalensi masing-masing kategori untuk mengetahui besaran masalah gizi pada balita.
Sistem Informasi Geografis atau Geographic Information System (GIS) merupakan sistem yang bertujuan menyajikan informasi geografi yang meliputi objekobjek yang ada di permukaan dan di dalam bumi yang disajikan sesuai dengan kebutuhan pengguna sistem. Hal-hal yang membedakan GIS dengan sistem lain yang utama adalah data terdiri dari data spatial atau grafis dan data tekstual. Software pendukung GIS terdiri dari software pemetaan untuk menyimpan dan memanipulasi data spatial.

GIS merupakan sebuah alat bantu manajemen berupa informasi berbantuan komputer yang berkait erat dengan sistem pemetaan dan analisis terhadap segala sesuatu serta peristiwa-peristiwa yang terjadi di muka bumi. Teknologi GIS mengintegrasikan operasi pengolahan data berbasis database yang biasa digunakan saat ini, seperti pengambilan data berdasarkan kebutuhan, serta analisis statistik dengan menggunakan visualisasi yang khas serta berbagai keuntungan yang mampu ditawarkan melalui analisis geografis melalui gambar-gambar petanya. Kemampuan tersebut membuat sistem informasi GIS berbeda dengan sistem informasi pada umumnya dan membuatnya berharga bagi perusahaan milik masyarakat atau perseorangan untuk memberikan penjelasan tentang suatu peristiwa, membuat peramalan kejadian, dan perencanaan strategis lainnya.

Suatu sistem informasi manajemen kesehatan termasuk diantaranya sistem informasi geografis PSG di kabupaten sangat penting untuk:

a. Penyusunan kebijakan kesehatan dan perencanaan kesehatan / perbaikan status gizi, terutama dalam hubungannya dengan pengalokasian sumberdaya di tingkat kabupaten. 
b. Pemantauan pelayanan dan program kesehatan/gizi

c. Penilaian dampak dalam perbaikan status kesehatan dan status gizi serta pemerataannya.

Dewasa ini penggunaan SIG diberbagai bidang diharapkan mampu memberikan kemudahan-kemudahan yang diinginkan yaitu:

a. Penanganan data geospasial menjadi lebih baik dalam format baku

b. Revisi dan pemutakhiran data menjadi lebih muda

c. Data geospasial dan informasi menjadi lebih mudah dicari, dianalisa dan direpresentasikan.

d. Menjadi produk yang mempunyai nila tambah.

e. Kemampuan menukar data geospasial

f. Penghematan waktu dan biaya.

g. Keputusan yang diambil menjadi lebih baik.

\section{METODE PENELITIAN}

Jenis penelitian ini termasuk research and development yakni penelitian yang bertujuan mengembangan aplikasi SIG untuk mendukung pemetaan status gizi balita. Cara dan alat pengumpulan data pada penelitian ini adalah observasi menggunakan instrumen lembar, wawancara menggunakan pedoman wawancara, merancang sistem informasi menggunakan alat Diagram Aliran Data (DAD) dan Entity Relationship Diagram (ERD). Data alamat spasial atau terrestrial lokasi puskesmas melalui pengukuran titik koordinat pada 21 wilayah puskesmas di Kabupaten Sukoharjo diukur menggunakan alat ukur Global Positioning System (GPS) Garmin III.
Tahapan pengembangan sistem informasi dapat dilakukan dengan menggunakan tahapan siklus hidup pengembangan sistem dari Whitten tahun 2001 dengan menggunakan metode FAST (Framework for the Application of System Techniques), yakni dengan tahapan: 1). studi pendahuluan; 2). Analisis masalah; 3). Analisis kebutuhan; 4). Analisis keputusan; 5). Perancangan. 6). Membangun Sistem Baru. Pada penelitian ini tahapan penerapan sistem baru belum bisa dilakukan karena luasnya ruang lingkup pengembangan

Analisis data secara deskriptif dengan menggambarkan dan menganalisis struktur dan prosedur informasi yakni segala sesuatu yang terkait dengan kegiatan pemantauan status gizi balita seperti subyek dan obyek yang terkait, permasalahan, ruang lingkup, alur pengumpulan informasi, mekanisme pelaporan serta cara penyajian informasi.

\section{HASIL DAN PEMBAHASAN}

\section{Analisis Masalah}

Titik penyebab permasalahan pada sistem informasi pemantauan status gizi balita dari hasil analisis masalah meliputi kecepatan, kemudahan, kelengkapan dan aksesibilitas yang berasal dari proses pengolahan data pemantauan status gizi balita serta pada proses penyimpanan data dan informasinya. Proses pengolahan dan penyimpanan data ini menjadi masalah karena sistem lama belum menggunakan pendekatan basis data sehingga mempersulit proses perubahan struktur data dan belum ada rancangan peta yang memudahkan penyajian dan interpretasi data.

\section{Analisis Kebutuhan}

Analisis entitas eksternal dan elemenelemen data yang akan dijadikan acuan 
untuk perancangan basis data. Hasil dari observasi terhadap formulir dan wawancara dengan staf gizi bahwa elemen data yang dibutuhkan meliputi: a). Data balita seperti nama, umur, jenis kelamin, berat badan, tinggi badan b). Data puskesmas seperti nama puskesmas dan alamat spasial puskesmas.

Kebutuhan informasi dapat dijelaskan secara ringkas sebagai berikut: a). Sistem informasi pemantauan status gizi balita yang akan dikembangkan dapat menghasilkan informasi secara cepat, mudah dan lengkap b). Sistem informasi dapat menghasilkan laporan berdasarkan wilayah puskesmas c). Sistem informasi dapat menghasilkan informasi berupa tabel dan peta secara otomatis d). Sistem informasi dapat menghasilkan informasi yang mudah diakses sesuai kebutuhan

\section{Analisis Keputusan}

Pada pengembangan sistem informasi pemantauan status gizi balita ini digunakan sistem operasi under Windows karena sistem operasi ini yang sedang digunakan di Dinas Kesehatan Sukoharjo sehingga operator telah terbiasa dengan sistem operasi tersebut.

Pemilihan Tools sistem informasi baru pada penelitian ini menggunakan Drupal
PHP sebagai tools pengembangan sistem informasi pemantauan status gizi balita dan Postgre SQL sebagai tools untuk pembuatan database, serta map server sebagai tools pembuatan peta.

\section{Perancangan}

Analisis terhadap kebutuhan informasi, entitas yang terkait dan elemen-elemen data yang dibutuhkan seperti yang telah diuraikan sebelumnya menjadi dasar dilakukannya pengembangan diagram konteks, pengembang-an DFD level 0, pengembangan DFD level 1 yang menggambarkan proses pemasukan data, pengolahan data dan pelaporan. Pada tahap ini juga dilakukan perancangan input, output, antar muka dan pembuatan peta digital. Pada perancangan input pemantauan status gizi balita ini selain data balita dan data puskesmas yang merukan elemen data utama, maka juga digunakan juga data input seperti indikator pemantauan seperta indeks $\mathrm{BB} / \mathrm{U}, \mathrm{BB} / \mathrm{TB}$, dan $\mathrm{TB} / \mathrm{U}$, sedangkan data standar rujukan menggunakan baku WHO/NCHS yang telah terstandarisasi. Data target atau pencapaian menyesuaikan dengan Departemen Kesehatan yakni untuk gizi baik minimal $80 \%$ dan gizi buruk maksimal $0,5 \%$.

Tabel 1. Rancangan Input Data Sistem Informasi Pemantauan Status Gizi Balita

\begin{tabular}{cllll}
\hline \hline No. & \multicolumn{1}{c}{ Nama Input } & \multicolumn{1}{c}{ Sumber } & Volume & Periode \\
\hline 1. & $\begin{array}{l}\text { Data balita (nama, umur, jenis kelamin, } \\
\text { berat badan, tanggal lahir, tinggi badan). }\end{array}$ & Hasil pemantauan & 1 Kab. & Tahunan \\
2. & Data puskesmas (nama, alamat spasial) & Hasil pengukuran & $1 \mathrm{Kab}$. & Tahunan \\
3. & Data indikator pemantauan & Seksi Gizi & $1 \mathrm{Kab}$. & Tahunan \\
4. & Data standar rujukan & Seksi Gizi & $1 \mathrm{Kab}$. & Tahunan \\
5. & Data target/goal program & Seksi Gizi & 1 Kab. & Tahunan \\
\hline
\end{tabular}

Sumber: Hasil Analisis 
Rancangan dialog antar muka (interface) dan tampilan output (tabel dan peta). Adapun rancangannya dapat dilihat pada Gambar 1.

Dialog antar muka pemasukan data puskesmas dengan pull down menu seperti terlihat pada Gambar 1. dengan memilih puskesmas mana yang data-data balitanya akan dimasukkan. Sesuai jumlah puskesmas di Kabupaten Sukoharjo puskesmas maka pilihan nama puskesmas dibuat berdasarkan nama-nama kecamatan. Prinsip dasar merancang software adalah bergantung pada faktor yang diinginkan, berupa kecepatan eksekusi atau kemudahan dalam pembuatan dan pemakaiannya (Whitten, 2001) (Gambar 1), juga menunjukkan data karakteristik balita yang diinput meliputi tanggal, bulan dan tahun lahir, juga data utama lainnya adalah data berat badan dan tinggi badan. Selain itu juga diisikan tanggal, bulan dan tahun penimbangan yang akan me-nentukan umur balita, karena status gizi balita akan di hitung menggunakan indeks $\mathrm{BB} / \mathrm{U}$ dan $\mathrm{BB} / \mathrm{TB}$ dengan rumus z-skor (Almatsir, 2001; Supariasa dkk., 2002).

Rancangan output dilakukan untuk mempermudah gambaran hasil yang diinginkan, selengkapnya tersaji pada Tabel 2.
Rancangan output juga meliputi rancangan mengenai rekapitulasi data status gizi balita seperti terlihat pada Gambar 2.

Data balita yang telah dimasukkan akan dapat dilihat tampilannya secara keseluruh-an melalui tabel rekapitulasi yang lebih informatif seperti pada Gambar 2. yang juga menunjukkan hasil analisis status gizi setiap balita. Kecepatan dalam membuat rekapitulasi hasil surveilens/ pemantauan ini merupakan salah satu indikator kinerja sistem berbasis komputer dibandingkan dengan sistem konvensional dalam mendukung fungsi-fungsi manajemen (Depkes RI, 2001; Jogiyanto, 2003), selain itu menunjukkan tampilan hasil PSG secara keseluruhan dengan hasil analisis setiap puskesmas dengan pembagian kategori status gizi balita berdasarkan pembedaan jenis kelamin. Tampilan ini didasarkan pada baku rujukan WHONCHS yang memilah status gizi berdasarkan jenis kelamin dan membaginya menjadi 4 kategori yakni status gizi baik, kurang, buruk dan lebih. (Almatsir, 2001; Supariasa dkk., 2002, Depkes RI, 2002)

Tabel 2. Rancangan Output Sistem Informasi Pemantauan Status Gizi Balita

\begin{tabular}{|c|c|c|c|c|c|c|}
\hline No. & Nama output & $\begin{array}{l}\text { For- } \\
\text { mat }\end{array}$ & Media & Alat & Distribusi & Periode \\
\hline 1. & Rekap laporan Puskesmas & Tabel & Kertas & Printer & $\begin{array}{l}\text { Seksi Gizi, Subdin } \\
\text { Kesga, Puskesmas }\end{array}$ & Tahunan \\
\hline 2. & Rekap laporan Kabupaten & Tabel & Kertas & Printer & $\begin{array}{l}\text { Kepala Dinas, Subdin } \\
\text { Kesga, Lintas Sektor }\end{array}$ & Tahunan \\
\hline 3. & Tabel status gizi Kabupaten & Tabel & Kertas & Printer & Kepala Dinas & Tahunan \\
\hline 4. & Peta status gizi Kabupaten & Peta & Kertas & Printer & Kepala Dinas & Tahunan \\
\hline
\end{tabular}

Sumber: Hasil Analisis 


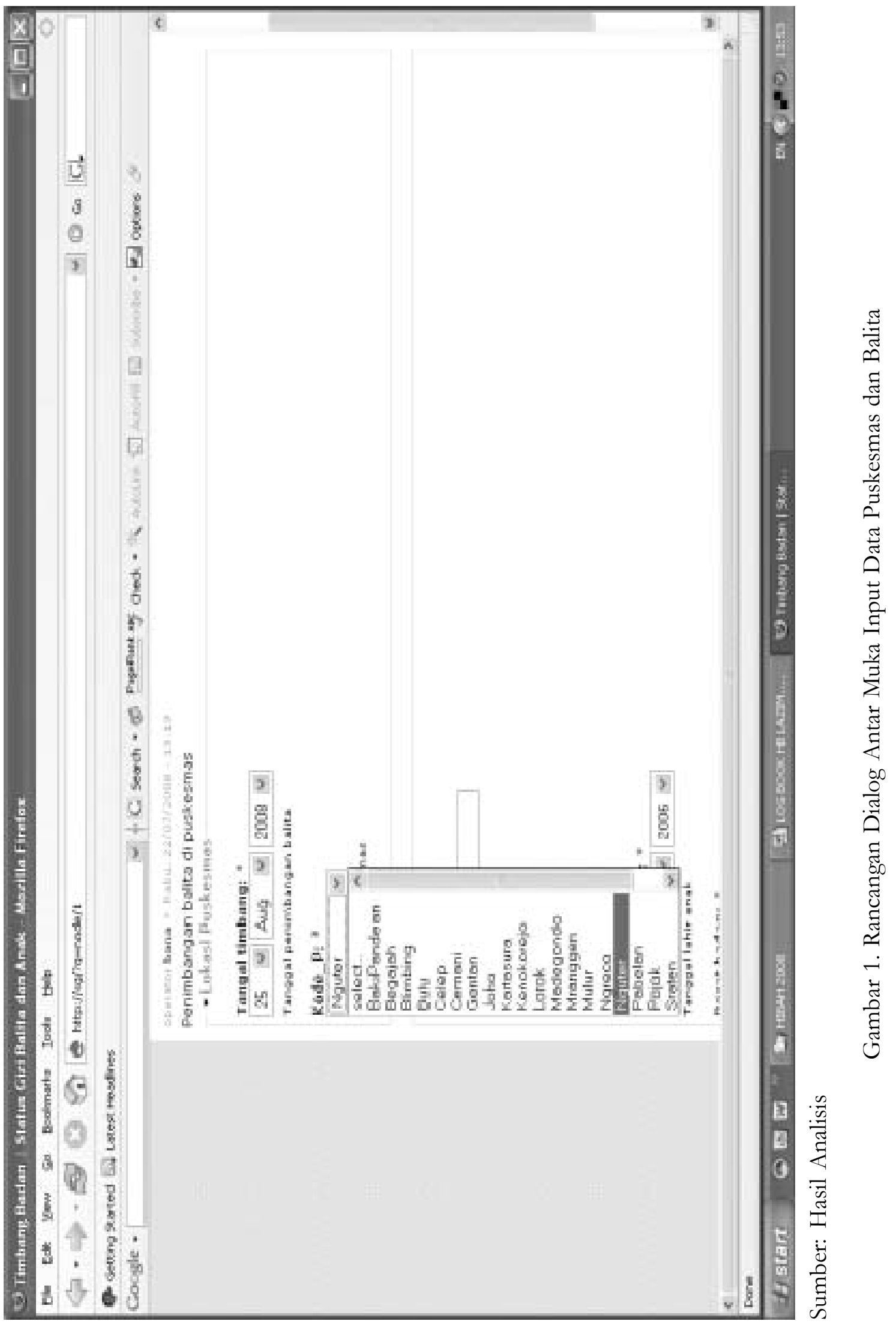




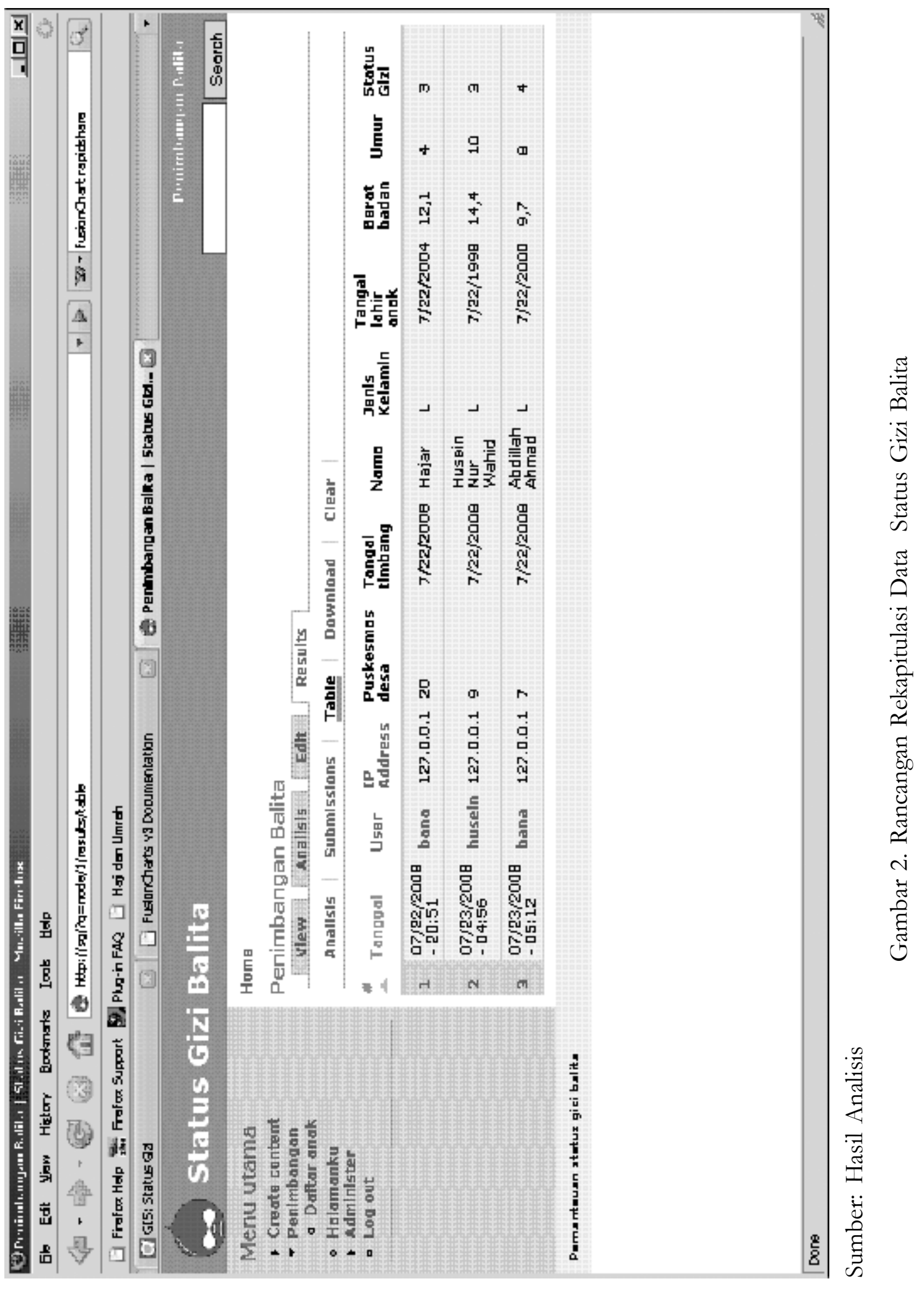

Aplikasi SIG pada Pemantauan Status Gizi ... (Mutalazimah, dkk.) 
Rancangan peta Kabupaten Sukoharjo sebagai basis pemetaan status gizi balita didasarkan pada hasil pengukuran alamat spasial puskesmas di wilayah Sukoharjo dapat dilihat pada Tabel 3.

Tabel 3. Data Koordinat Titik Lokasi Puskesmas Kabupaten Sukoharjo

\begin{tabular}{|c|c|c|c|}
\hline \multirow{2}{*}{ No } & \multicolumn{2}{|c|}{ Koordinat Titik } & \multirow{2}{*}{ Alamat } \\
\hline & $\mathbf{X}$ & $\mathbf{Y}$ & \\
\hline 1 & 486147,26131694 & 9144470,93932427 & Jl. Raya Nguter no 370, Desa Nguter, Kec Nguter \\
\hline 2 & 481570,57047134 & 9141616,24734076 & Desa Bulu, Kecamatan Bulu \\
\hline 3 & 477551,62560241 & 9144835,29922317 & Jl. yos Sudarso, Desa Lorog, Kec. Tawangsari \\
\hline 4 & 473399,32142010 & 9142302,61563123 & Jl. Beringin no 9, Desa Ngreco, Kecamatan weru \\
\hline 5 & 480542,04439627 & 9148571,59745778 & $\begin{array}{l}\text { Jl Raya Banmati, Desa Banmati Bedingin, Kec. } \\
\text { Sukoharjo }\end{array}$ \\
\hline 6 & 481939,39071095 & 9151562,25366920 & $\begin{array}{l}\text { Jl. Jaksa Agung R. Suprapto no 17, Kel. } \\
\text { Sukoharjo }\end{array}$ \\
\hline 7 & 486136,23084808 & 9149787,52330932 & Jl. Dr. Muwardi, Desa Mulur, Kec. Bendosari \\
\hline 8 & 487117,63099737 & 9152145,12316981 & Desa Kenokorejo, Kec. Polokarto \\
\hline 9 & 488521,58597580 & 9156877,31731111 & $\begin{array}{l}\text { Jl. Raden Ngabei Poncopranoto, Desa Mranggen, } \\
\text { Polokarto }\end{array}$ \\
\hline 10 & 485790,74763158 & 9159656,13807278 & $\begin{array}{l}\text { Dukuh Kebak, RT 01/RW 12, Desa Wirun, Kec. } \\
\text { Mojolaban }\end{array}$ \\
\hline 11 & 486951,06253375 & 9161958,62929139 & Dukuh Jatimalang, Desa Joho, Kec. Mojolaban \\
\hline 12 & 480057,52441934 & 9159878,84904829 & $\begin{array}{l}\text { Jl. Raya Grogol no 47, Desa Madegondo, Kec. } \\
\text { Grogol }\end{array}$ \\
\hline 13 & 478011,50213073 & 9162143,35254071 & $\begin{array}{l}\text { Jl. Batik Keris RT 01/RW } 12 \text {, Dukuh Candi, } \\
\text { Cemani, Grogol }\end{array}$ \\
\hline 14 & 476399,27568130 & 9159164,35085689 & $\begin{array}{l}\text { Jl. WR. Supratman no 20, Desa Kadilangu, Kec. } \\
\text { Baki }\end{array}$ \\
\hline 15 & 476120,27822101 & 9162138,88869223 & JL. Rajawali no 2, Desa Gentan, Kec. Baki \\
\hline 16 & 471312,21604419 & 9160334,00526237 & Dukuh Tanon, Desa Blimbing, Kec. Gatak \\
\hline 17 & 469194,77563700 & 9162541,16939570 & Desa Sraten, Kec. Gatak \\
\hline & & & Jl. Raya Solo-Jogja, Desa Pucangan, Kec. \\
\hline 18 & 470498,04526922 & 9165065,96315150 & Kartasura \\
\hline 19 & 474141,49589972 & 9164289,99626831 & Jl. A. Yani, Desa Pabelan, Kec. Kartasura \\
\hline
\end{tabular}

Sumber: Data Primer Hasil Pengukuran GPS 
Berdasarkan hasil pengukuran titik koordinat lokasi puskesmas seperti tersaji pada Tabel 3. Maka dikembangkan rancangan peta yang dapat dilihat pada Gambar 3.

Selanjutnya rancangan peta ini direlasikan dengan basis data status gizi balita, dengan hasil tampilan pada Gambar 4.

\section{Membangun Sistem Baru}

Pada tahap membangun sistem baru ini dilakukan dua kegiatan yakni pemrograman dan pengujian sistem. Pemrograman diawali dengan pertama, perancangan basis data, tabel-tabel basis data dibuat menggunakan bahasa pemrograman dengan Postgre SQL. Kedua, perancangan form input data yang digunakan untuk pemasukan data dibuat menggunakan bahasa pemrograman dengan drupal php dan model menu push button interactive, yakni dengan cara menekan tombol-tombol interaktif yang telah tersedia. Ketiga, pembuatan laporan, dengan menghubung-kan masing-masing tabel dalam basis data dan siap di cetak langsung dari form pemasukan data. Keempat, pembuatan peta menggunakan tools map server.

Pengujian yang dilakukan adalah pengujian sistem, yang dilakukan dengan menguji sistem secara keseluruhan untuk memastikan sistem dapat bekerja sesuai fungsi dan kebutuhan yang diharapkan. Pengujian sistem ini dilakukan dengan melakukan simulasi pemasukan data-data balita yang meliputi nama, tanggal, bulan dan tahun kelahiran, jenis kelamin, dan ukuran antropometri seperti berat badan dan tinggi badan. Selain itu juga simulasi pemasukan data tanggal, bulan dan tahun penimbangan dan nama puskesmas. Selanjutnya dilakukan pengujian fungsional sistem informasi pada proses perhitungan status gizi, rekapitulasi hasil dan gambar peta yang sesuai dengan hasil analisis.

\section{KESIMPULAN}

Aplikasi SIG sangat bermanfaat pada kegiatan pemantauan status gizi balita di Kabupaten Sukoharjo karena sebenarnya kegiatan ini telah mempunyai struktur dan prosedur yang jelas mulai dari subyek pelaksana, proses pengumpulan, pengolahan dan pelaporan data tetapi selama ini masih dilakukan secara konvensional. Pengembangan sistem informasi pemantauan status gizi balita yang memenuhi kriteria mudah, cepat, informatif berbasis SIG yang diharapkan dapat memperbaiki kinerja dan tampilan sistem agar semakin baik, efektif dan efisien. Pengembangan SIG ini dapat mendukung kegiatan pemantauan status gizi balita dan meningkatkan keberhasilan program perbaikan gizi.

\section{UCAPAN TERIMA KASIH}

Terima kasih penulis ucapkan kepada DP2M Dikti atas dana hibah penelitian, Ketua Lembaga Penelitian dan Pengabdian pada Masyarakat UMS atas pembinaan dan pengarahan yang diberikan, Dekan Fakultas Ilmu Kesehatan UMS atas segala dukungannya, Dinas Kesehatan Sukoharjo yang telah mengijinkan sebagai lokasi penelitian dan seluruh pihak terkait yang tidak dapat disebutkan satu per satu. 


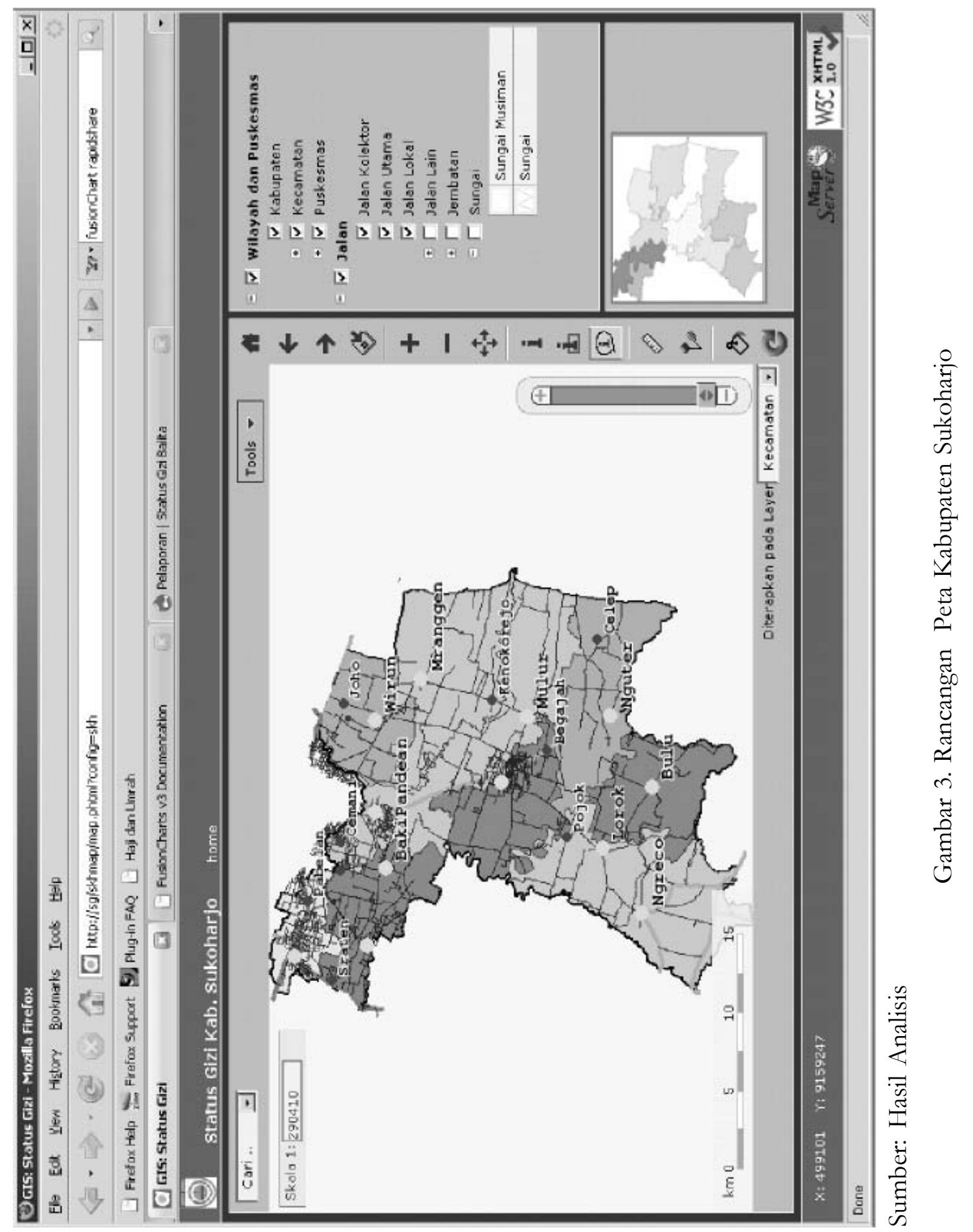




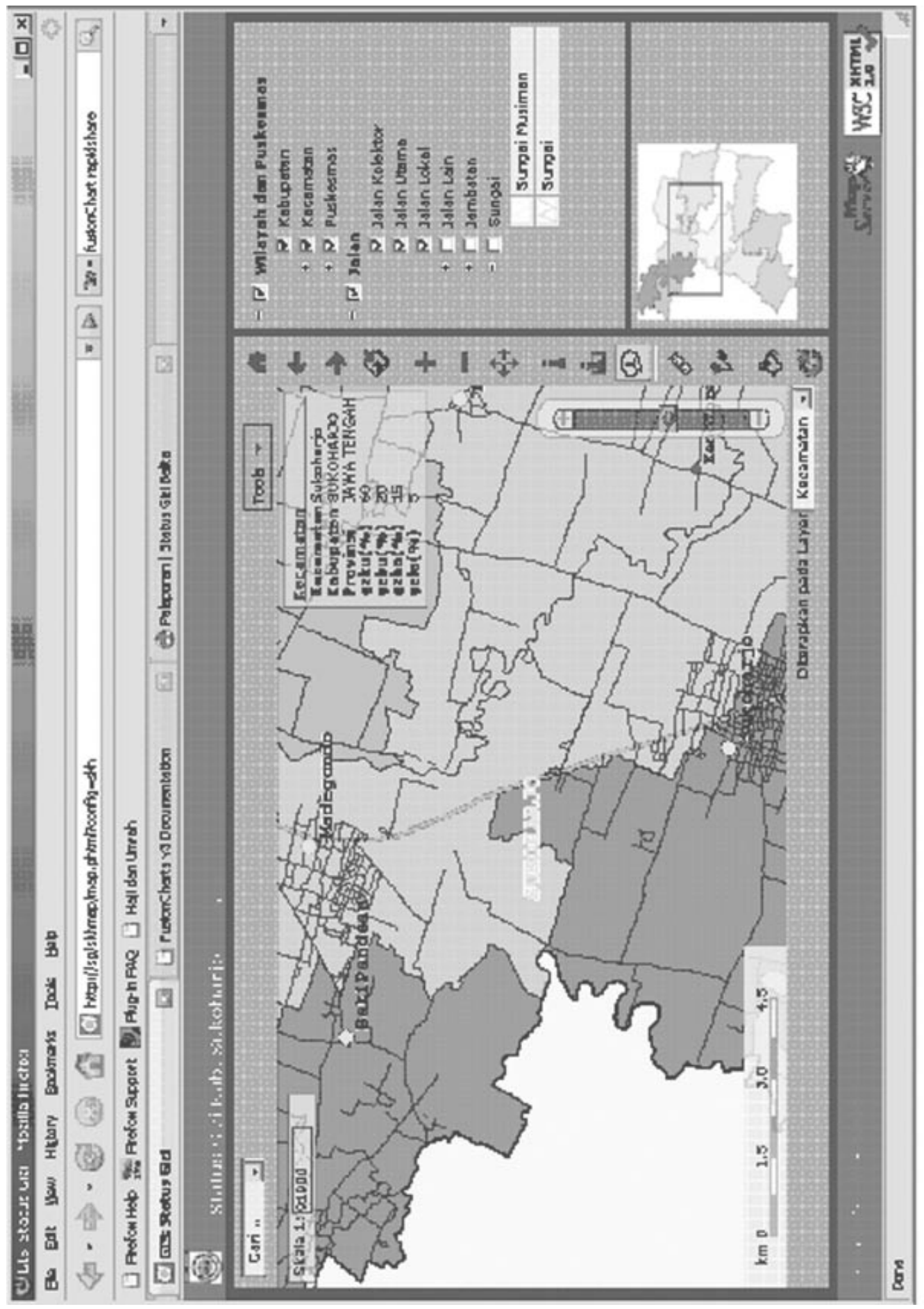

吾

.

Aplikasi SIG pada Pemantauan Status Gizi ... (Mutalazimah, dkk.) 


\section{DAFTAR PUSTAKA}

Almatsier, Sunita. 2001. Prinsip Dasar Ilmu Giæi. Gramedia Pustaka Utama .Jakarta

Anonim, 2005. Geographic Information System : Mapping Solution, http://www. Scomptec.htm, 12 April 2005.

Depkes RI. 2000. Strategi dan Kebijakan Pembangunan Kesehatan Menuju Indonesia Sebat 2010. Depkes RI. Jakarta

Depkes RI. 2001. Dukungan Informasi Untuk. Manajemen Kesebatan di Kabupaten/Kotamadya, Pusat Data Kesehatan Depkes RI, Jakarta.

Depkes RI. 2002. Pedoman Pemantauan Status Giz̨i. Direktorat Bina Gizi Masyarakat Depkes RI. Jakarta.

Hartono, Meteray, T. B. S., Farda, N. M., Kamal, M.. 2006. Kajian Ekosistem Air Permukaan Rawa Biru-Torasi Merauke Papua Menggunakan Citra Penginderaan Jauh dan SIG. Forum Geografi. Vol. 20 (1) Juli 2006: 2.

Husein, Rahmat, 2006, Konsep Dasar Sistem Informasi Geografis, Ilmu Komputer.com, diakses 11 November 2009.

Jogiyanto, HM.2003. Sistem Teknologi Informasi. Penerbit Andi, Yogyakarta.

Mutalazimah; Handaga, Bana, 2005, Pengembangan Sistem Informasi Manajemen Pemantauan Status Giri Balita, Laporan Penelitian, UMS

Mutalazimah; Handaga, Bana, 2006, Pengembangan Sistem Informasi Manajemen Berbasis Komputer Pada Kegiatan Pemantauan Garam Beryodium, Laporan Penelitian, UMS

Ridwan, Ali, 2008, Landasan Teori Sistem Informasi Geografis, Artikel Tutorial GIS, STT Telkom, diakses 11 November 2009.

Supariasa, I Nyoman Dewa. Bakri, Bachyar. Fajar, Ibnu. 2002. Penilaian Status Gizi. EGC Penerbit Buku kedokteran, Jakarta.

Whitten, JL; Bentley, LD and Dittman, KC. 2001. System Analysis and Design Methods, Mc Graw Hill, New York. 